\title{
Perilaku Pemeliharaan Kesehatan Gigi dan Mulut Ibu Hamil di Puskesmas Bahu Manado
}

\author{
${ }^{1}$ Wulan P.J. Kaunang, ${ }^{1}$ Vonny Wowor, ${ }^{2}$ Adiska Devinta Arisanty \\ ${ }^{1}$ Dosen di Fakultas Kedokteran Universitas Sam Ratulangi \\ ${ }^{1}$ Dosen di Program Studi Kedokteran Gigi Fakultas Kedokteran Universitas Sam Ratulangi \\ ${ }^{2}$ Mahasiswa Program Studi Kedokteran Gigi Fakultas Kedokteran \\ Universitas Sam Ratulangi Manado \\ Email : Adiskaarisanty@gmail.com
}

\begin{abstract}
ABSTRAK
Pemeliharaan kesehatan gigi dan mulut selama kehamilan bertujuan untuk mencegah terjadinya masalah kesehatan gigi dan mulut saat masa kehamilan. Kesehatan gigi dan mulut merupakan salah satu hal yang perlu diperhatikan selama kehamilan. Kondisi kesehatan gigi dan mulut ibu hamil yang buruk dapat memberikan dampak pada kehamilan seperti kelahiran prematur, dan bayi dengan berat badan lahir rendah (BBLR), dan preeklampsia. Tujuan penelitian ini untuk mengetahui perilaku pemeliharaan kesehatan gigi dan mulut ibu hamil yang mencakup pengetahuan, sikap, dan tindakan. Jenis penelitian ini bersifat deskriptif dengan pendekatan cross sectional yang melibatkan 50 orang ibu hamil di Puskesmas Bahu Manado. Pengumpulan data diperoleh melalui kuesioner yang meliputi karakteristik responden, pengetahuan, sikap, dan tindakan pemeliharaan kesehatan gigi dan mulut responden. Hasil penelitian menunjukkan bahwa pengetahuan pemeliharaan kesehatan gigi dan mulut ibu hamil di Puskesmas Bahu Manado tergolong baik, dengan perolehan skor 473 (78,8\%), sikap pemeliharaan kesehatan gigi dan mulut ibu hamil di Puskesmas Bahu Manado tergolong baik, dengan perolehan skor 558 (93\%), dan tindakan pemeliharaan kesehatan gigi dan mulut ibu hamil di Puskesmas Bahu Manado tergolong baik, dengan perolehan skor $502(83,7 \%)$. Kesimpulan dari penelitian ini adalah pengetahuan, sikap, tindakan pemeliharaan kesehatan gigi dan mulut ibu hamil di Puskesmas Bahu Manado tergolong baik.
\end{abstract}

Kata kunci : Perilaku Ibu hamil, pemeliharaan kesehatan gigi dan mulut

\begin{abstract}
Maintenance of oral health during pregnancy aims to prevent oral health problems during pregnancy. Oral health is one of the things that need attention during pregnancy. Dental and oral health of pregnant women are poor, which can hqve an impact on pregnancy as premature births, babies with low birth weight ( $L B W)$, and preeclampsia. The purpose of this study to determine the oral health care behavior of pregnant women that include knowledge, attitudes, and actions. This is a descriptive research with cross-sectional design among 50 pregnant women at health centers Bahu Manado. The data collected by questionnaires that include respondent characteristics, knowledge, attitudes, and actions of oral health care respondents. The results showed that oral health care knowledge of pregnant women in Bahu Manado health centers was good, with a score of 473 (78.8\%), oral health care attitudes of pregnant women in Bahu Manado health centers was good, with a score of 558 (93\%) and oral health care maintenance actions of pregnant women in Bahu Manado health centers was good, with a score of 502 (83.7\%). Conclusion this study that knowledge, ,attitudes, and actions oral health care of pregnant women in Bahu Manado health centers was good.
\end{abstract}

Key words: oral health behavior of pregnant women, oral health care 


\section{PENDAHULUAN}

Setiap ibu hamil perlu menjaga kesehatan selama kehamilan, termasuk kesehatan gigi dan mulut. kondisi kesehatan gigi dan mulut ibu hamil yang buruk dapat memberikan dampak pada kehamilan dan perkembangan janin. ${ }^{1}$

saat kehamilan terjadi perubahan hormonal yaitu hormon estrogen dan progesteron. Perubahan hormonal pada ibu hamil menimbulkan berbagai keluhan seperti ngidam, mual, muntah dan termasuk keluhan sakit gigi dan mulut akibat dari kebiasaan mengabaikan kebersihan gigi dan mulut. ${ }^{2}$ Menurut Riset Kesehatan Dasar (Riskesdas), penduduk Indonesia pada tahun 2007 mengalami masalah kesehatan gigi dan mulut yaitu karies dan penyakit periodontal. Penduduk yang mengalami masalah kesehatan gigi dan mulut tentu saja termasuk ibu hamil. ${ }^{3}$

Ibu hamil harus menyadari pentingnya menjaga kesehatan mulut selama kehamilan untuk dirinya sendiri serta janin yang dikandung sehingga dapat menghindari terjadinya penyakit mulut yang dapat memengaruhi kehamilan. Oleh karena itu peningkatan kesehatan gigi dan mulut serta promosi kesehatan dapat mengurangi terjadinya penyakit mulut. ${ }^{4}$

Saat ini banyak perhatian yang ditujukan pada kesehatan gigi dan mulut ibu hamil karena diduga ada hubungannya dengan penyakit periodontal dan masalah kehamilan seperti kelahiran prematur, bayi dengan berat lahir rendah (BBLR), dan preeklampsia. ${ }^{5}$ Hal ini dipengaruhi oleh perilaku buruk ibu hamil terhadap pemeliharaan kesehatan gigi dan mulut selama masa kehamilan. Penyakit mulut yang terjadi selama masa kehamilan bukan semata-mata hanya dipengaruhi oleh kehamilan itu sendiri melainkan juga oleh pengetahuan, sikap, dan tindakan ibu hamil. ${ }^{6}$ Penelitian Mwaiswelo pada tahun 2006 menunjukkan kurangnya pengetahuan ibu hamil terhadap pemeliharaan kesehatan gigi dan mulut dimana hanya $16 \%$ dari ibu hamil yang menerima pendidikan kesehatan gigi dan mulut, $97 \%$ menyikat giginya, $52 \%$ dari ibu hamil percaya menyikat gigi secara rutin akan mengurangi risiko terjadinya masalah pada gusi dan hanya $3,7 \%$ ibu hamil mengunjungi dokter gigi selama kehamilan. Perilaku kunjungan ke dokter gigi dipengaruhi oleh faktor- faktor seperti faktor personal, status ekonomi dan pengetahuan mengenai hubungan kesehatan gigi dan mulut. $^{7}$

Puskesmas Bahu merupakan salah satu sarana pelayanan kesehatan masyarakat yang ada di kota Manado yang memberikan layanan kuratif, preventif, promotif, dan rehabilitatif. Menurut survei awal yang dilakukan oleh penulis, kunjungan ibu hamil untuk memeriksakan kesehatan gigi dan mulutnya ke poliklinik gigi sekitar 3,8\%. Keluhan yang dialami misalnya gigi belubang dan penyakit periodontal seperti gingivitis dan periodontitis.

Sosialisasi mengenai pemeliharaan kesehatan gigi dan mulut selama masa kehamilan masih jarang dilakukan di puskesmas tersebut. Ibu hamil juga lebih banyak memeriksakan kehamilannya dibandingkan dengan memeriksakan kesehatan gigi dan mulut. Sejauh ini penelitian tentang perilaku pemeliharaan kesehatan gigi dan mulut ibu hamil di Puskesmas Bahu Manado belum pernah dilakukan.

Berdasarkan hal-hal di atas, maka penulis tertarik untuk melakukan penelitian mengenai perilaku pemeliharaan kesehatan gigi dan mulut ibu hamil di Puskesmas Bahu Manado.

\section{BAHAN DAN METODE}

Jenis penelitian yang digunakan yaitu penelitian deskriptif dengan menggunakan 
pendekatan Cross sectional study.

Penelitian ini dilakukan di Puskesmas

Bahu Manado pada bulan Juni-Juli 2013.

Populasi dalam penelitian ini adalah ibu hamil yang berkunjung di Puskesmas Bahu Manado pada saat penelitian berlangsung sebanyak 50 orang.

Kriteria inklusi pada penelitian ini yaitu ibu hamil yang berkunjung di Puskesmas Bahu Manado, ibu hamil yang bersedia mengisi kuesioner, ibu hamil yang tidak buta huruf, dan dapat berkomunikasi dengan baik.

Teknik pengambilan sampel dalam penelitian ini menggunakan metode Total sampling, yaitu semua populasi yang

memenuhi kriteria inklusi dijadikan sebagai sampel.

Variabel penelitian ini terdiri dari perilaku, pemeliharaan kesehatan gigi dan mulut, serta ibu hamil.

Perilaku pemeliharaan kesehatan gigi dan mulut ibu hamil yang meliputi pengetahuan, sikap, dan tindakan diukur dengan kuesioner, dimana masing-masing diberikan 6 pertanyaan. Setiap pertanyaan diberi skor 2 untuk jawaban tahu, setuju, dan ya, sedangkan 1 untuk jawaban tidak tahu, tidak setuju, dan tidak.

Jumlah skor tertinggi 2x6x50 $=600$

Jumlah skor terendah $1 \times 6 \times 50=300$

Berdasarkan data yang didapat, maka perilaku pemeliharaan kesehatan gigi dan mulut ibu hamil di Puskesmas Bahu Manado yang meliputi pengetahuan, sikap, dan tindakan, maka dapat dirumuskan dengan menggunakan rumus persentase sebagai berikut:

\section{$\mathrm{X} / 600 \times 100 \%=\mathrm{Y}$}

Hasil tersebut dikategorikan menjadi 2 kategori yaitu kurang dan baik.

$\begin{array}{rrr}300 & 450 & 600 \\ 0 \% & 50 \% & 100 \%\end{array}$

Kurang Baik

\section{HASIL PENELITIAN}

A. Karakteristik responden

Karakakteristik responden dapat dilihat pada table 1, 2, 3, dan 4 .

Tabel 1. Distribusi karakteristik responden berdasarkan usia.

\begin{tabular}{ccc}
\hline Usia & $\mathrm{n}$ & $\%$ \\
\hline$<20$ tahun & 5 & 10 \\
$20-29$ tahun & 30 & 60 \\
$30-39$ tahun & 13 & 26 \\
$>40$ tahun & 2 & 4 \\
\hline Total & 50 & 100 \\
\hline
\end{tabular}

Sebagian besar responden banyak dijumpai pada kelompok 20-29 tahun yaitu sebanyak 30 responden (60\%). Untuk kelompok usia 30 - 39 tahun sebanyak 13 responden (26\%), kelompok usia $<20$ tahun sebanyak 5 responden (10\%), sedangkan sebagian kecil responden termasuk pada kelompok usia > 40 tahun sebanyak 2 responden (4\%).(tabel 1)

Tabel 2. Distribusi karakteristik responden berdasarkan pekerjaan

\begin{tabular}{ccc}
\hline Pekerjaan & $\mathrm{N}$ & $\%$ \\
\hline PNS & 1 & 2 \\
Wiraswasta & - & - \\
IRT & 42 & 84 \\
Lain-lain & 7 & 14 \\
\hline Total & 50 & 100 \\
\hline
\end{tabular}

Pekerjaan responden yang paling banyak dijumpai terdapat pada kategori ibu rumah tangga, yaitu 42 responden (84\%). Untuk kategori pekerjaan lain sebanyak 7 responden dimana responden yang bekerja sebagai pegawai swasta sebanyak 6 responden (12\%), 1 responden (2\%) sebagai mahasiswa, dan sebagian kecil dari responden berada pada kategori (14\%) pegawai negeri (PNS) hanya 1 responden (2\%) saja. (tabel 2) 
Tabel 3. Distribusi karakteristik responden berdasarkan pendidikan terakhir

\begin{tabular}{ccc}
\hline Pendidikan terakhir & $\mathrm{n}$ & persentase \\
\hline Tidak sekolah & - & - \\
SD & 4 & 8 \\
SMP & 4 & 8 \\
SMA & 39 & 78 \\
Perguruan tinggi & 3 & 6 \\
\hline Total & 50 & 100 \\
\hline
\end{tabular}

Tingkat pendidikan terakhir responden yang paling banyak dijumpai terdapat pada responden dengan tamatan Sekolah Menengah Atas (SMA) yaitu sebanyak 39 responden $(78 \%)$. Untuk responden dengan tamatan SD dan SMP masing-masing berjumlah 4 responden (8\%), sedangkan sebagian kecil pendidikan responden berada pada kategori Perguruan Tinggi yang berjumlah 3 responden (6\%).
Tabel 4. Distribusi karakteristik respoden berdasarkan jumlah kehamilan

\begin{tabular}{ccc}
\hline Jumlah kehamilan & N & Persentase \\
\hline 1 kali & 14 & 2 \\
2 kali & 22 & 44 \\
3 kali & 10 & 20 \\
$>3$ kali & 4 & 6 \\
\hline Total & 50 & 100 \\
\hline
\end{tabular}

Sebagian besar responden telah mengalami kehamilan 2 kali yaitu sebanyak 22 responden (44\%). Untuk responden yang telah mengalami kehamilan 1 kali sebanyak 14 responden (28\%), responden yang mengalami kehamilan 3 kali sebanyak 10 responden $(20 \%)$, sedangkan sebagian kecil responden dijumpai pada kategori jumlah kehamilan > 3 kali hanya 4 responden $(6 \%)$. (tabel 4)

B. Perilaku responden dalam pemeliharaan kesehatan gigi dan mulut

Perilaku responden dapat dilihat pada tabel $5,6,7$.

Tabel 5. Distribusi pengetahuan responden dalam pemeliha raan kesehatan gigi dan mulut

\begin{tabular}{|c|c|c|c|c|c|c|}
\hline \multirow{2}{*}{ No } & \multirow[t]{2}{*}{ Pernyataan } & \multicolumn{2}{|c|}{ Tahu } & \multicolumn{2}{|c|}{ Tidak tahu } & \multirow{2}{*}{$\begin{array}{c}\text { Skor } \\
\text { penilaian }\end{array}$} \\
\hline & & $\mathrm{n}$ & $\%$ & $\mathrm{n}$ & $\%$ & \\
\hline 1. & $\begin{array}{l}\text { Menyikat gigi secara rutin dapat mengurangi } \\
\text { risiko terjadinya penyakit gigi dan mulut }\end{array}$ & 37 & 74 & 13 & 26 & 87 \\
\hline 2 & $\begin{array}{l}\text { Penggunaan benang gigi dapat membantu } \\
\text { menyingkirkan sisa makanan di sela-sela gigi }\end{array}$ & 7 & 14 & 43 & 86 & 57 \\
\hline 3. & $\begin{array}{l}\text { Berkumur setelah muntah dapat } \\
\text { menetralisisir asam di mulut sehingga } \\
\text { mengurangi risiko kerusakan pada gigi }\end{array}$ & 29 & 58 & 21 & 42 & 79 \\
\hline 4. & $\begin{array}{l}\text { Vitamin A dan C dapat mengurangi risiko } \\
\text { terjadinya } \\
\text { radang gusi. }\end{array}$ & 25 & 50 & 25 & 50 & 75 \\
\hline 5. & $\begin{array}{l}\text { Konsumsi makanan dan minuman dengan } \\
\text { kadar gula } \\
\text { yang tinggi dapat meningkatkan } \\
\text { frekuensi gigi berlubang. }\end{array}$ & 41 & 82 & 9 & 18 & 91 \\
\hline 6. & $\begin{array}{l}\text { Pemeriksaan gigi secara rutin selama } \\
\text { kehamilan dapat membantu mengoptimalkan } \\
\text { kesehatan gigi dan mulut ibu hamil. }\end{array}$ & 34 & 68 & 16 & 32 & 84 \\
\hline & Total & & & & & 473 \\
\hline
\end{tabular}


Berdasarkan skor hasil perhitungan keseluruhan, maka pengetahuan pemeliharaan kesehatan gigi dan mulut ibu hamil di Puskesmas Bahu Manado memperoleh skor 473 dengan persentase $78,8 \%$. (tabel 6)

Hasil tersebut diperoleh dari rumus persentase sebagai berikut :

$$
\begin{gathered}
\mathrm{X} / 600 \times 100 \%=\mathrm{Y} \\
473 / 600 \times 100 \%=78,8 \%
\end{gathered}
$$

Hasil tersebut apabila dimasukkan pada skala pengukuran akan terlihat bahwa pengetahuan tentang pemeliharaan kesehatan gigi dan mulut ibu hamil di Puskesmas Bahu

Manado tergolong pada kategori baik.(Gambar 1)

300

$0 \%$

$\begin{array}{ccr}450 & & 600 \\ 50 \% & \mathbf{4 7 3} & 100 \% \\ & \mathbf{7 8 , 8 \%} & \end{array}$

Baik
Gambar 1. Kategori hasil pengukuran pengetahuan ibu hamil dalam pemeliharaan kesehatan gigi dan mulut

\begin{tabular}{|c|c|c|c|c|c|c|}
\hline \multirow{2}{*}{ No } & \multirow[t]{2}{*}{ Pernyataan } & \multicolumn{2}{|c|}{ Setuju } & \multicolumn{2}{|c|}{ Tidak setuju } & \multirow{2}{*}{$\begin{array}{c}\text { Skor } \\
\text { penilaian }\end{array}$} \\
\hline & & $\mathrm{n}$ & $\%$ & $\mathrm{n}$ & $\%$ & \\
\hline 1. & $\begin{array}{l}\text { Selama kehamilan sebaiknya ibu menyikat } \\
\text { gigi secara rutin. }\end{array}$ & 50 & 100 & 0 & 0 & 100 \\
\hline 2 & $\begin{array}{l}\text { Setelah penyikatan gigi sebaiknya perlu } \\
\text { dilanjutkan dengan pembersihan di sela-sela } \\
\text { gigi dengan penggunaan benang gigi. }\end{array}$ & 22 & 44 & 28 & 56 & 72 \\
\hline 3. & $\begin{array}{l}\text { Setelah muntah ibu sebaiknya langsung } \\
\text { berkumur menggunakan air }\end{array}$ & 50 & 100 & 0 & 0 & 100 \\
\hline 4. & $\begin{array}{l}\text { Selama kehamilan ibu sebaiknya } \\
\text { Mengonsumsi makanan yang banyak } \\
\text { mengandung vitamian A dan C. }\end{array}$ & 50 & 100 & 0 & 0 & 100 \\
\hline 5. & $\begin{array}{l}\text { Ibu sebaiknya mengonsumsi buah-buahan di } \\
\text { antara waktu makan. }\end{array}$ & 50 & 100 & 0 & 0 & 91 \\
\hline 6. & $\begin{array}{l}\text { Selama kehamilan ibu harus lebih sering } \\
\text { melakukan pemeriksaan gigi secara rutin }\end{array}$ & 36 & 72 & 14 & 28 & 86 \\
\hline & Total & & & & & 558 \\
\hline
\end{tabular}

Tabel 6. Distribusi sikap responden dalam pemeliharaan kesehatan gigi dan mulut

Berdasarkan skor hasil perhitungan keseluruhan, maka pengetahuan pemeliharaan kesehatan gigi dan mulut ibu hamil di Puskesmas Bahu Manado memperoleh skor 558 dengan persentase $93,0 \%$. (tabel 6)

Hasil tersebut diperoleh dari rumus persentase sebagai berikut :

$$
\begin{gathered}
\mathrm{X} / 600 \times 100 \%=\mathrm{Y} \\
558 / 600 \times 100 \%=93,0 \%
\end{gathered}
$$

Hasil tersebut apabila dimasukkan pada skala pengukuran akan terlihat bahwa pengetahuan tentang pemeliharaan kesehatan gigi dan mulut ibu hamil di Puskesmas Bahu Manado tergolong pada kategori baik.(Gambar 2)

300

450 600

$0 \%$ $50 \%$ $558100 \%$ 93,0\%

\section{Kurang}

Baik

Gambar 2. Kategori hasil pengukuran sikap ibu hamil dalam pemeliharaan kesehatan gigi dan mulut 
Tabel 7. Distribusi tindakan responden dalam pemeliharaan kesehatan gigi dan mulut

\begin{tabular}{|c|c|c|c|c|c|c|}
\hline \multirow{2}{*}{ No } & \multirow{2}{*}{ Pernyataan } & \multicolumn{2}{|c|}{ Ya } & \multicolumn{2}{|c|}{ Tidak } & \multirow{2}{*}{$\begin{array}{c}\text { Skor } \\
\text { penilaian }\end{array}$} \\
\hline & & $\mathrm{n}$ & $\%$ & $\mathrm{n}$ & $\%$ & \\
\hline 1. & Ibu menyikat gigi secara rutin $2 \times$ sehari & 48 & 96 & 2 & 4 & 98 \\
\hline 2. & $\begin{array}{l}\text { Ibu menggunakan benang gigi setelah } \\
\text { menyikat gigi }\end{array}$ & 3 & 6 & 47 & 94 & 53 \\
\hline 3. & $\begin{array}{l}\text { Ibu langsung berkumur } \\
\text { dengan air setelah muntah }\end{array}$ & 49 & 98 & 1 & 2 & 99 \\
\hline 4. & $\begin{array}{l}\text { Ibu mengonsumsi makanan } \\
\text { yang banyak mengandung } \\
\text { vitamin } \mathrm{A} \text { dan } \mathrm{C}\end{array}$ & 48 & 96 & 2 & 4 & 98 \\
\hline 5. & $\begin{array}{l}\text { Ibu lebih banyak mengonsumsi buah- } \\
\text { buahan di antara waktu makan. }\end{array}$ & 44 & 96 & 6 & 12 & 94 \\
\hline 6. & $\begin{array}{l}\text { Ibu memeriksakan kesehatan gigi dan mulut } \\
\text { selama kehamilan pada dokter gigi setiap } 6 \\
\text { bulan sekali }\end{array}$ & 10 & 20 & 40 & 80 & 60 \\
\hline & Total & & & & & 502 \\
\hline
\end{tabular}

Berdasarkan skor hasil perhitungan keseluruhan, maka tindakan pemeliharaan kesehatan gigi dan mulut ibu hamil di Puskesmas Bahu Manado memperoleh skor 502 dengan persentase $83,7 \%$. (tabel 7)

Hasil tersebut diperoleh dari rumus persentase sebagai berikut :

$$
\begin{gathered}
\mathrm{X} / 600 \times 100 \%=\mathrm{Y} \\
502 / 600 \times 100 \%=83,7 \%
\end{gathered}
$$

Selanjutnya hasil tersebut apabila dimasukkan pada skala pengukuran akan terlihat bahwa pengetahuan tentang pemeliharaan kesehatan gigi dan mulut ibu hamil di Puskesmas Bahu Manado tergolong pada kategori baik. (Gambar 3)

$\begin{array}{lccc}300 & 450 & & 600 \\ & & & \\ 0 \% & 50 \% & \mathbf{5 0 2} & 100 \% \\ & & \mathbf{8 3 , 7 \%} & \end{array}$

Kurang Baik

Gambar 3. Kategori hasil pengukuran tindakan ibu hamil dalam pemeliharaan kesehatan gigi dan mulut

\section{PEMBAHASAN}

Dalam penelitian ini rata-rata perolehan skor untuk pengetahuan pemeliharaan kesehatan gigi dan mulut ibu hamil di Puskesmas Bahu Manado termasuk pada kategori baik 473 $(78,8 \%)$. Hasil penelitian ini menunjukkan bahwa hampir seluruh responden memiliki pengetahuan yang baik mengenai upaya pemeliharaan kesehatan gigi dan mulut selama kehamilan. Hal ini ditunjukkan melalui pemahaman responden terbanyak terhadap dampak mengonsumsi makanan kariogenik dapat meningkatkan frekuensi terjadinya gigi berlubang yakni $82 \%$ responden.Karbohidrat dalam makanan yang sifatnya paling dapat merusak ialah jenis sukrosa. Camilan seperti coklat, manisan, dan makanan manis lainnya merupakan makanan yang mengandung gula sehingga dapat merusak gigi dan meningkatkan frekuensi karies jika dikonsumsi untuk jangka waktu yang lama serta sering mengabaikan kebersihan gigi dan mulut. ${ }^{8,9}$ Hasil yang sama juga ditunjukkan oleh penelitian yang dilakukan oleh Natalie J Thomas di Australia pada tahun 2008 bahwa $84 \%$ ibu hamil mengetahui mengonsumsi makanan manis dapat menyebabkan gigi berlubang. ${ }^{31}$ Suatu penelitian di Arab Saudi pada tahun 2005 menunjukkan 77,4 \% ibu hamil yang 
mengonsumsi makanan dan minuman manis di antara jam makan, menempatkan mereka pada risiko karies tinggi. ${ }^{32}$ Pemahaman yang baik juga ditunjukkan oleh $74 \%$ responden yang mengetahui tentang manfaat menyikat gigi secara rutin dapat mengurangi risiko terjadinya penyakit gigi dan mulut. Mengenai pemeriksaan gigi secara rutin selama kehamilan, pada penelitian ini $68 \%$ responden mengetahui tentang pentingnya pemeriksaan gigi secara selama kehamilan dapat membantu mengoptimalkan kesehatan gigi dan mulut sehingga meminimalkan terjadinya komplikasi penyakit gigi dan mulut.

Demikian juga dalam hal berkumur setelah muntah yaitu sebanyak 58\% responden mengetahui manfaat berkumurkumur dengan air setelah muntah bagi kesehatan gigi. Dalam penelitian ini, 50\% responden mengetahui tentang manfaat vitamin $\mathrm{A}$ dan $\mathrm{C}$ bagi kesehatan gusi.

Banyaknya informasi yang dipublikasikan melalui media, baik lewat media cetak maupun media elektronik juga menjadi penyebab tingginya pengetahuan responden. Pengetahuan juga dapat diperoleh melalui pengalaman seseorang. Pada penelitian sebagian besar responden telah mengalami kehamilan sebanyak dua kali atau lebih yaitu $72 \%$ responden. Ibu yang mengandung anak kedua atau anak ketiga lebih banyak memiliki pengalaman dalam upaya pemeliharaan kesehatan gigi dan mulut daripada anak pertama sehingga memiliki banyak informasi mengenai hal tersebut.

Pada penelitian ini responden yang memiliki pemahaman terendah yaitu pengetahuan responden mengenai upaya pemeliharaan melalui penggunaan benang gigi yakni, hanya $14 \%$ responden yang mengetahui manfaat penggunaan benanggigi. Kurangnya pengetahuan responden disebabkan karena di Indonesia penggunaan benang gigi belum cukup populer. Hasil ini berbeda dengan penelitian Natalie J Thomas di Australia pada tahun 2008 yang menunjukkan $84 \%$ ibu hamil mengetahui bahwa dengan menggunakan benang gigi dapat mengurangi masalah kesehatan gigi dan mulut. ${ }^{31}$ Penggunaan benang gigi berfungsi untuk mengangkat sisa-sisa makanan yang terdapat pada sela-sela gigi. Sisa makanan yang dibiarkan menempel pada sela-sela gigi dapat menyebabkan plak gigi

Sikap ibu hamil dalam pemeliharaan kesehatan gigi dan mulut di Puskesmas Bahu Manado secara keseluruhan baik dengan perolehan skor 558 (93\%). Kesadaran yang ditunjukkan melalui sikap mereka yang baik disebabkan karena setiap responden yang mempunyai kesediaan untuk berubah. Hal ini sesuai dengan salah satu teori perubahan perilaku yang dikemukakan oleh WHO, yang menyatakan bahwa salah satu alasan seseorang menunjukkan sikap dalam hal memperoleh kesehatan adalah suatu inovasi yang dapat memotivasi responden., ${ }^{9,10}$ Melalui inovasi atau program-program kesehatan, responden mengadopsi nilai-nilai yang baik berkaitan dengan upaya pemeliharaan kesehatan gigi dan mulut, sehingga mereka memiliki kesediaan untuk berubah.

Hasil penelitian menunjukkan bahwa seluruh responden $(100 \%)$ memiliki sikap yang baik dalam pemeliharaan kesehatan gigi dan mulut selama kehamilan. Pemeliharaan kesehatan gigi dan mulut selama kehamilan ini meliputi, anjuran untuk menyikat gigi secara rutin, berkumur dengan air setelah muntah, mengonsumsi makanan yang banyak mengandung vitamin A dan $\mathrm{C}$ serta mengonsumsi buah-buahan di antara waktu makan sebagai pengganti camilan. Hal ini menunjukkan bahwa mungkin responden telah memahami dengan baik tentang tujuan menyikat gigi, berkumur setelah muntah, manfaat vitamin A dan C, serta dampak dari konsumsi makanan yang manis bagi kesehatan gigi dan mulut.

Kesadaran yang dimiliki responden, 
membuat mereka tertarik untuk lebih memerhatikan kesehatan gigi dan mulutnya. Terbukti $72 \%$ memiliki sikap positif untuk melakukan pemeriksaan kesehatan gigi selama kehamilan. Walaupun demikian, masih ada $28 \%$ responden yang tidak setuju dengan pemeriksaan kesehatan gigi dan mulut dimana responden merasa takut untuk melakukan perawatan gigi karena hal tersebut akan membahayakan bayi yang dikandungnya. Hasil ini hampir sebanding dengan penelitian oleh Sunita Bamanikar dan Liew Kok Kee di Brunei Darussalam pada tahun 2010 yang menemukan 96,8\% ibu hamil menunjukkan sikap positif terhadap kontrol ke dokter gigi selama kehamilan. ${ }^{34}$ Kesadaran paling rendah ditunjukkan responden terhadap anjuran penggunaan benang gigi setelah penyikatan gigi yaitu $56 \%$, hal ini sejalan dengan pengetahuan responden yang masih rendah tentang penggunaan benang gigi. Namun sikap sebagai perwujudan pengetahuan menunjukkan peningkatan, yakni sebesar 44\% setuju penggunaan benang gigi setelah menyikat gigi. Peningkatan ini mungkin disebabkan karena adanya pemberian informasi tambahan oleh penulis tentang manfaat penggunaan benang gigi saat penelitian berlangsung.

Tindakan pemeliharaan kesehatan gigi dan mulut ibu hamil di Puskesmas Bahu Manado sudah dapat dikatakan baik, dimana $83,7 \%$ responden telah memiliki tindakan tersebut. Tindakan para ibu hamil merupakan perwujudan pengetahuan dan sikap yang telah dimiliki sebelumnya, sehingga tindakan dikatakan sebagai perilaku terbuka.

Tindakan pemeliharaan kesehatan gigi dan mulut responden secara keseluruhan baik. Hal ini ditunjukkan dengan sikap yang baik dalam menjaga kesehatan gigi dan mulutnya selama kehamilan, dan itu diwujudkan melalui tindakan nyata yang dilakukan responden di puskesmas tersebut Hampir seluruh ibu hamil (96\%) rajin menyikat gigi dengan frekuensi 2 kali sehari Hasil ini hampir sama dengan penelitian Sunita Bamanikar dan Liew Kok kee di Brunei Darussalam pada tahun 2010 yang mendapatkan $100 \%$ responden menyikat gigi secara rutin. ${ }^{34}$. Tindakan menyikat gigi yang baik dilakukan setiap hari dengan frekuensi 2 - 3 kali. Tindakan berkumur dengan air setelah muntah dilakukan oleh 98\% responden. Hasil ini menunjukkan tindakan berkumur sebagian besar responden pada penelitian ini sedikit lebih baik dibandingkan dengan penelitian Dewi Diana di Medan pada tahun 2009 yang menemukan $87 \%$ responden berkumur dengan air setelah muntah. ${ }^{17}$ Tindakan ini sangat baik, karena keadaan rongga mulut berubah menjadi asam dengan pH 1 - 1,5 akibat dari muntah-muntah. Asam dalam mulut dapat menyebabkan kerusakan pada gigi, seperti abrasi. Tindakan yang baik juga dilakukan oleh 96\% responden lewat mengonsumsi makanan yang banyak mengandung vitamin A dan C. Mengonsumsi vitamin pada saat hamil merupakan hal yang penting untuk kesehatan ibu hamil sendiri maupun janin yang sedang dikandung, dimana vitamin akan memberi nutrisi penting yang diperlukan tubuh terutama saat kehamilan. Di samping untuk kesehatan gusi, vitamian A dapat berfungsi sebagai imunitas dan pertumbuhan janin. Selanjutnya dalam menghindari makanan kariogenik, diperoleh hasil hampir seluruh responden (88\%) menghindarinya dengan mengonsumsi buahbuahan di antara waktu makan.

Dalam penelitian ini tindakan penggunaan benang gigi dan pemeriksaan rutin kesehatan gigi dan mulut ke dokter gigi selama kehamilan masih kurang. Responden yang melakukan penggunaan benang gigi hanya $6 \%$ responden saja. Hal ini sejalan dengan pengetahuan dan sikap yang dimiliki oleh responden.yang kurang. Hal ini mungkin juga disebabkan karena ketersediaan fasilitas, misalnya tempat pembelian benang gigi. Faktor lingkungan juga menjadi penyebab 
seseorang untuk bertindak dikarenakan kurangnya masyarakat yang menggunakan benang gigi di Indonesia. Hasil ini berbeda dengan penelitian di Brunei Darussalam pada tahun 2010 yang mendapat persentase cukup tinggi yakni 40,9\% ibu hamil yang menggunakan benang gigi. ${ }^{34}$

Untuk tindakan kunjungan ke dokter gigi selama kehamilan, diperoleh $20 \%$ responden melakukan pemeriksaan ke dokter gigi karena adanya keluhan seperti sakit gigi, gigi berlubang, gusi berdarah, dan lain-lain. Rendahnya tindakan responden tidak sejalan dengan pengetahuan dan sikap tentang pemeriksaan rutin ke dokter gigi selama kehamilan. Penulis berasumsi bahwa selama kehamilan mungkin ibu hamil tidak mempunyai waktu mengunjungi dokter gigi karena kesibukan pekerjaan atau mengunjungi klinik bersalin, menyiapkan pakaian atau kamar untuk calon bayinya. Sehingga selama kurun waktu tersebut ibu mengabaikan perawatan rongga mulutnya, baik dalam menjaga kebersihan mulut maupun pengontrolan ke dokter gigi. Di samping itu, mungkin faktor ekonomi dapat menghambat responden untuk melakukan pemeriksaan secara rutin ke dokter gigi. Biaya berobat ke dokter gigi cukup terasa mahal bagi sebagian orang, sehingga apabila dilihat dari latar belakang pendidikan responden yang kebanyakan berpendidikan SMA akan sangat mendukung. Kebanyakan masyarakat dengan latar belakang pendidikan SMA digaji berkisar pada upah minimum regional (UMR), sehingga dengan pendapatan yang terbatas disertai kebutuhan ekonomi yang meningkat pada masa kehamilan menyebabkan kunjungan rutin ke dokter gigi tidak menjadi prioritas utama.

Keadaan ekonomi yang tinggi juga menunjang seseorang untuk mendapatkan pelayanan kesehatan. Hal tersebut didukung oleh penelitian Kristen S. Marchi dkk pada tahun 2007 bahwa hambatan keuangan menjadi faktor penyebab ibu hamil tidak melakukan pemeriksaan ke dokter gigi. ${ }^{35}$

Hasil penelitian ini juga didukung oleh penelitian yang dilakukan oleh Dewi Diana di Medan pada tahun 2009 yakni hanya $8 \%$ responden mengunjungi dokter gigi saat hamil, dimana $7 \%$ responden berkunjung ke dokter gigi dengan alasan adanya keluhan dan $1 \%$ responden melakukan kontrol kesehatan gigi dan mulut. ${ }^{17}$

\section{SIMPULAN}

1. Pengetahuan ibu hamil tentang pemeliharaan kesehatan gigi dan mulut di Puskesmas Bahu Manado tergolong dalam kategori baik dengan perolehan skor $473(78,8 \%)$.

2. Sikap ibu hamil terhadap pemeliharaan kesehatan gigi dan mulut di Puskesmas Bahu Manado tergolong dalam kategori baik dengan perolehan skor 558 (93\%).

3. Tindakan ibu hamil dalam pemeliharaan kesehatan gigi dan mulut di Puskesmas Bahu Manado tergolong dalam kategori baik dengan perolehan skor $502(83,7 \%)$.

\section{SARAN}

Bagi mayarakat, khususnya Ibu hamil, dapat mempertahankan perilaku yang baik dalam hal pemeliharaan kesehatan gigi dan mulut selama masa kehamilan, serta lebih meningkatkan perilaku kunjungan ke dokter gigi selama kehamilan. Bagi institusi kesehatan, adanya partisipasi dari tenaga kesehatan di puskesmas oleh dokter gigi maupun dokter kandungan dalam program promosi kesehatan gigi dan mulut ibu hamil terutama mengenai kunjungan ke dokter gigi selama kehamilan dalam rangka meningkatkan kesehatan gigi dan mulut ibu hamil dan hasil perinatal yang baik. Bagi institusi pendidikan dan peneliti, adanya penelitian lebih lanjut dengan melibatkan populasi yang lebih luas untuk mengevaluasi kondisi rongga mulut ibu hamil dan mencari 
hubungan antara perilaku pemeliharaan kesehatan gigi dan mulut dengan kondisi kesehatan rongga mulut ibu hamil.

\section{DAFTAR PUSTAKA}

1. Bartini I. Asuhan kebidanan pada ibu hamil normal Ed. ke-1. Yogyakarta: Nuha Medika; 2012. Hal. 2.

2. GajendraS, Kumar JV. Oral health and pregnancy: A review. NYSDJ 2004: 402.

3. Depertemen Kesehatan Republik Indonesia. Laporan Riset Kesehatan Dasar Nasional 2007. Jakarta: Badan Penelitian dan Pengembangan Kesehatan; 2008.

4. Bugrant O, Levent O, Basak F, Altun C, Acikel C. Turkish women's self reported knowledge and behavior towards oral health during pregnancy. Med princ pract 2012;21:318 - 22 .

5. Abiola A, Olayinka A, Mathilda B, Ogunbiyi O, Modupe S, Olobunmi O. Survey of the oral health knowledge and practices of pregnant woman in Nigerian teaching hospital. African $\mathrm{J}$ of repro health 2011;15(4):14 - 9.

6. Piere M, Cooke I, Linden G, Irwin C. Review dental manifestation of dental pregnancy. J royal collage obstetric and gynaecologist 2007;9:21 - 6.

7. Mwaiswelo RO, Masalu JR. Oral health knowledge and behavior among pregnant women in Keyla District, Mabeya, Tanzania. Tanzania dent J 2007;14(2):47 -52 .

8. Colgate oral care and the university of Adelaide. Pregnancy and oral health. Colgate caries control program [serial online] 2009 [cited 2013 April 24]. Available from:URL:http www.arcpoh.adelaide.edu.au/dperu /c aries/ cariesinfo/cariesinfo9.pdf

9. Council on clinical affairs. Guideline on perinatal oral health care for the pregnant adolescent. Clinical guidelines [serial online] 2007 [cited 2013 April 24]
Availablefrom:_URL:http//www.aapd.org /media/policies/guidline/Gpreg- nacy.pdf

10. Thomas NJ, Middleton PF, Crowther CA. Oral and dental health care practices in pregnant women in Australia. Biomed Central 2008;8(13):1 - 6

11. Al-Truck K. Dental care and dietary habits of Saudi pregnant women in a prenatal clinic in Riyadh. Pakistan oral and Dent.Jr 2005 June;25(1):75 - 9.

12. Nursalam, Pariani. Konsep Tingkat Pengetahuan. [serial online] 2010 [cited 2013 September 5]. Available from:URL:http://id.shvoong.com/humani ties linguistics/2053284-konsep-tingkatpengetahuan/

13. Bamanikar S, Kee KL. Knowledge, attitude and practice dental health care in pregnant women. Oman Medical J 2013;28(4):288 - 91.

14. Marchi KS, Fisher-Owen SA, Weintraub JA, Yu Z, Braveman PA. Most pregnant women in California do not receive dental care: Findings from a populationbased study. Public Health Rep 2010 Nov-Dec,125(6):831 - 42 
